This is a pre-copyedited, author-produced version of an article accepted for publication in Parliamentary Affairs following peer review. The version of record Philip Norton, Departmental Select Committees: The Reform of the Century?, Parliamentary Affairs, , gsz043 is available online at: https://doi.org/10.1093/pa/gsz043.

\title{
Departmental Select Committees: The Reform of the Century?
}

Philip Norton

On Monday, 25 June 1979, the British House of Commons sat at its usual time of 2.30 p.m. At 3.45 p.m., after Question Time, Norman St John-Stevas, Chancellor of the Duchy of Lancaster and Leader of the House of Commons, rose to move a motion appointing 12 select committees 'to examine the expenditure, administration and policy of the principal government departments', with power to send for persons, papers and records and to appoint persons with technical knowledge 'either to supply information which is not readily available or to elucidate matters of complexity within the committee's order of reference'. The members were to be appointed for the lifetime of a Parliament, and with the order establishing the committees being a standing order of the House. The order also empowered committees to sit notwithstanding the adjournment of the House, to report from time to time and for some to appoint sub-committees. It also provided for the appointment (in effect, the continuation) of a committee to examine the reports of the Parliamentary Commissioner for Administration as well as setting the maximum membership of each committee: either 9,10 or 11 in the case of the departmental select committees.

The debate was crucial in establishing a set of committees - departmental select committeeswhich were to be central to the life of the House of Commons. St John-Stevas said the changes 'could constitute the most important parliamentary reforms of the century' (House of Commons Debates, 25 June 1979, c. 35). The observation was aspirational. Select committees were not new to the House. They had a long, but chequered, history. The gestation period of the new set of committees was a long one-the proposals to set up departmental select committees were not exclusive to the Procedure Committee that reported in 1978-and their continued existence by no means certain. The motion moved by St John-Stevas was approved by 248 votes to 12 . The size of the majority rather masked the difficult birth of the committees.

Select committees were well established in parliamentary history. As Kenneth Mackenzie recorded, 'The principle of the committee is almost as old as parliament itself' (Mackenzie, 1968, p. 47). The first reference in the parliamentary journals to the appointment of select committees was in 1571, though it is likely that this was not the first time they had been utilised (Campion, 1958, pp. 25-26). In that year, a committee was set up 'for the subsidy', another for 'matters of religion', and a third for 'matters of griefs and petitions' (Mackenzie, 1968, p. 49). The Journal of 1605 includes a timetable of committees sitting every day of the week. The use of committees, whether for bills or for matters, was, as Mackenzie noted, 'well established by the middle of the seventeenth century' (Mackenzie, 1968, p. 50). In the 18th century, select committees were regularly appointed to consider petitions for bills, but a 'special type of select committee, usually consisting of 21 Members, chosen by ballot, was sometimes set up to inquire into matters of great importance' (Sedgwick, 1970, p. 8). Such appointments were not necessarily helpful to government. 'Except for the secret committee set up in 1715 to inquire into the late peace negotiations, other ballots of this kind were unfavourable to the Government' (Sedgwick, 1970, p. 8). 
This is a pre-copyedited, author-produced version of an article accepted for publication in Parliamentary Affairs following peer review. The version of record Philip Norton, Departmental Select Committees: The Reform of the Century?, Parliamentary Affairs, , gsz043 is available online at: https://doi.org/10.1093/pa/gsz043.

Their use declined in number and significance with the rise of party government in the 19th century. As Nevil Johnson recorded, the development of party and cabinet government ensured that the affairs of state were subject to the will of a Commons' majority. 'And it was a direct consequence of this constitutional development that within the House a permanent and specialized distribution of functions to committees was held to be unnecessary' (Johnson, 1979, p. 428). The party in government was not minded to support specialised committees that could submit it to sustained scrutiny. 'Ministers ... can hardly be expected to welcome procedures which are designed to make ... criticism more effective' (Hill and Whichelow, 1964, p. 66). Government and opposition pitted themselves against one another in adversarial conflict in the chamber. Executive-legislative relations were characterised by what Anthony King termed the opposition mode (King, 1976; see also Norton, 2019a). What committees that were utilised on a regular basis were those that facilitated passage of government measures. Standing committees, set up on ad hoc basis to take the committee stage of bills, were creatures of government, both in formation and activity. Behaviour in standing committees was a continuation of party behaviour in the chamber.

Pressure to create select committees to cover specific subjects or scrutinise departments was a feature of the 20th century. Proposals for a set of committees to cover government departments were made by the Haldane Committee, set up to consider the machinery of government, in 1918 (Ministry of Reconstruction, 1918, p. 15, para. 53). Such committees, it noted, 'would require to be furnished with full information as to the course of administration pursued by the Departments with which they were concerned; and for this purpose it would be requisite that Ministers, as well as the officers of Departments, should appear before them to explain and defend the acts for which they were responsible.' The committee expressed, in terms that have not been bettered since, the case for such committees:

It is not for us to attempt to forecast the precise procedure under which interrogations and requests for papers emanating from such Committees should be dealt with. But the particular argument in favour of some such system to which we feel justified in drawing attention is that if Parliament were furnished, through such Committees of its members, with fuller knowledge of the work of Departments, and of the objects which Ministers had in view, the officers of Departments would be encouraged to lay more stress upon constructive work in administering the services entrusted to them for the benefit of the community than upon anticipating criticism which may, in present conditions, often be based upon imperfect knowledge of the facts or the principles at issue. (Ministry of Reconstruction, 1918, p. 15, para. 54).

In the event, nothing happened. Similar proposals were made by a range of politicians. In 1964, in What's Wrong with Parliament?, its two pseudonymous authors, Andrew Hill and Anthony Whichelow (in practice, two Commons' clerks, Kenneth Bradshaw and David Pring) observed, 'A remarkable range of political commentators over the last thirty or forty years have advocated the use of specialist committees' (Hill and Whichelow, 1964, p. 65; see also Hansard Society, 1967, pp. 45-60, and Aylett, 'Reform and consolidation' in this issue), including MPs such as Leo Amery, Christopher Hollis, Lloyd George and Jo Grimond, former parliamentary officials Lord Campion and Sir Edward Fellowes and academics including Sir Ivor Jennings, Denis Brogan and Kenneth Wheare. This last category was augmented in 1964, when Bernard Crick argued the case in his influential The 
This is a pre-copyedited, author-produced version of an article accepted for publication in Parliamentary Affairs following peer review. The version of record Philip Norton, Departmental Select Committees: The Reform of the Century?, Parliamentary Affairs, , gsz043 is available online at: https://doi.org/10.1093/pa/gsz043.

Reform of Parliament, though the emphasis was on subject committees rather than departmental committees. The case for more extensive committees was then taken up by some reform-minded members returned in 1966 and by the Leader of the House of Commons, Richard Crossman, introducing a small number of select committees, both subject and departmental.

The Crossman reforms, as we will see in this issue (Aylett, 'Reform and consolidation'), formed an important precedent for what later followed. There were then recommendations for a series of departmental select committees from both the Expenditure Committee in 1977 and, crucially, a Commons Procedure Committee in 1978. The Procedure Committee was appointed in June 1976 to consider the practices and procedure of the House and make recommendations 'for the more effective performance of its functions'. It had been established with the support of both government and opposition front benches largely because-as Philip Aylett shows later in this volume-neither saw it as a threat, believing it would address procedural issues, such as working hours. No radical departures were envisaged, certainly not in respect of select committees, and certainly not under a chair who was not regarded as a dynamic or reforming parliamentarian. In the event, the committee's report was wide-ranging and included recommendations for the creation of 12 small departmentally related select committees, with widely drawn terms of reference and appointed by permanent standing orders.

The report constituted a clear, authoritative and reasoned reform agenda. However, such an agenda was necessary, but not sufficient, to achieve change. What had also been lacking until that point was the political will to achieve change. Although there were some committed reformers in the House in the 1960s, they were in a minority. The Labour Party embraced radical social reform, but it tended to be constitutionally conservative (Dorey, 2008). The select committees that were appointed as part of the Crossman reforms were essentially executive-inspired and dependent on executive indulgence. They were limited in number. When the Agriculture Committee sought to investigate the adequacy of the Agriculture Ministry's study of the effects of membership of the European Communities, it ran into opposition from the Foreign Office. As the Procedure Committee noted delicately in its 1978 report, the committee 'experienced some difficulty in establishing a modus vivendi with the relevant Government Departments' (Procedure Committee, 1978, p. xlix). In the following session, reflecting who was in charge, it was announced that the committee would not be re-appointed. During its twoyear existence, the government responded to none of its reports (Norton, 1981, p. 130).

The potential for having committees on other subjects failed to gain traction. When in 1967 Crossman raised with Prime Minister Harold Wilson the possibility of having a select committee on foreign affairs, 'I saw Burke [Sir Burke Trend, the Cabinet Secretary] purse his lips and Harold open his mouth and I realise that it's extremely unlikely that this will ever happen' (Crossman, 1976, p. 466). Although Wilson variously expressed support for creating some committees (see Aylett in this volume), he appears to have ascribed little importance to their creation (Dorey, 2008, p. 372). In 1969 , he told the cabinet that the experiment with specialist committees would be ended and left to the next Parliament to decide whether to keep them permanently. Crossman records: 
This is a pre-copyedited, author-produced version of an article accepted for publication in Parliamentary Affairs following peer review. The version of record Philip Norton, Departmental Select Committees: The Reform of the Century?, Parliamentary Affairs, , gsz043 is available online at: https://doi.org/10.1093/pa/gsz043.

This took my breath away. The end of the experiment, as though we had written it off as a failure. He [Wilson] started this Parliament keen on the whole idea of parliamentary reform and specialist committees but now they are getting going and standing up to the executive he has had nothing but complaints from Whitehall about the extra work it has caused and he has surrendered to the insistence that we should cut them back. (Crossman, 1977, p. 348).

The wariness on the part of ministers was longstanding. Former Leader of the House, R. A. Butler, in evidence to the Procedure Committee in 1959, described the proposal for specialist committees as 'a muddle in the constitution' that would 'get in the way of administration and blur responsibility' (Hill and Whichelow, 1964, p. 66; see also Aylett). Crossman was swimming against, rather than with, the ministerial tide.

The recommendations of the Procedure Committee may have gone the way of earlier proposals were it not for a change in behaviour and attitude of MPs. The backbench tide, at least, began to change. After the return of a Conservative government in 1970, Tory backbenchers, frustrated by government policies and a prime ministerial reluctance to heed their concerns, took their dissatisfaction into the division lobbies (Norton, 1978). Labour MPs followed suit in expressing their disagreement with their leaders after Labour was returned to office in 1974 (Norton, 1980). Behavioural change contributed to an attitudinal change, MPs wanting to be more involved in scrutinising and influencing policy than was previously the case (Norton, 1983, p. 67). MPs could exercise power through the division lobbies, but it was a blunt and reactive means of affecting outcomes and in any event still limited by the ultimate commitment to party. The opposition mode continued to rule in the chamber. However, pressing for the extension of select committees, exercising no coercive powers, but providing a constructive role for backbenchers, appeared to square the circle. There was thus a mood in the House favouring change. The report of the Procedure Committee offered the means of realising that change.

The proposals for the departmental select committees were not the only ones designed to achieve a greater role for backbenchers. The recommendations in the Procedure Committee report covered the content and drafting of legislation, control of delegated legislation, increasing influence over European legislation and improving financial control (Procedure Committee, 1978). There were proposals for other reforms emanating from members and reform bodies. Crick, with Commons clerk Michael Ryle, formed in 1964 the Study of Parliament Group (SPG), a body bringing together academics and clerks (Englefield, 1985). It embraced reform and advanced various proposals, though the case for departmental select committees did not figure prominently among the initial changes it advocated. In evidence to the Procedure Committee, it said it appeared desirable 'to establish a more systematic distribution of committee work, which would reflect the interests of all Members'. However, as Dermot Englefield recorded, 'it did not however anticipate the radical recommendations that would be made and the Departmental Select Committee system that would be set up during session 1979-80' (Englefield, 1985, p. 28). That it did not do so is not that surprising given the range of reforms being pursued. The SPG examined proposals affecting legislation, membership of the European Communities, financial control and the services and facilities available to MPs. Nor were changes secured in the 1979-1983 Parliament confined to the establishment of departmental select committees. During it, provision was made for referral of Bills to Special 
This is a pre-copyedited, author-produced version of an article accepted for publication in Parliamentary Affairs following peer review. The version of record Philip Norton, Departmental Select Committees: The Reform of the Century?, Parliamentary Affairs, , gsz043 is available online at: https://doi.org/10.1093/pa/gsz043.

Standing Committees, empowered to take evidence prior to normal standing committee stage. Estimates Days were introduced, the National Audit Office was established (National Audit Act 1983), Opposition Days replaced Supply Days and European Community documents could be referred to a Standing Committee on European Community Documents. The list is not exhaustive (see Norton, 1986, pp. 69-97).

These reforms came about against a backdrop of support from members for change to existing practices and procedures. However, this groundswell of support did not engulf all. Resistance to the proposal for departmental select committees came from a key figure in the form of Michael Foot, Leader of the House at the time the Procedure Committee's report was published. Although he conceded a two-day debate on the report, held on 19-20 February 1979, he was opposed to having a vote on its recommendations. He used his speech on the second day to develop the case against utilising select committees. 'It is my opinion', he declared, 'that if we set up the 12 Committees to examine the matters in the report on a regular basis we shall have not merely a further draining away of attention from the Chamber ... but the strength of Parliament being increasingly transferred to such Committees, thereby injuring the position of individual Members' (House of Commons Debates, 20 February 1979, c. 292-293). The committees, he argued, would also 'become a shield for the Departments' (House of Commons Debates, 20 February 1979, c. 293).

Foot advanced the classic arguments against what opponents saw as a novel threat to the role of the chamber. In 1959, the Procedure Committee had dismissed the proposal for specialist committees as a radical constitutional innovation (Hansard Society, 1967, p. 60). Foot found some support on the backbenches from two fellow Labour traditionalists, Sydney Irving, MP for Dartford and Willie Hamilton, MP for Fife Central. Irving said he was not against the committees in principle, but advanced what he saw as potential practical difficulties: 'It would ... mean the end to the role of the Back Bencher as an all-rounder.' The committees, he said, would develop a bureaucracy which, because of volume of work, 'would very soon be rubber-stamping the reports of the bureaucracy' (House of Commons Debates, 19 February 1979, c. 58). Some speakers also engaged in special pleading for existing select committees, such as that on Nationalised Industries, which would disappear under the Procedure Committee recommendations.

A different view came from Foot's fellow traditionalist, Ulster Unionist Enoch Powell, who argued that, rather than constituting a radical departure, what was recommended was a natural progression: the committees 'will simply be doing more thoroughly, more consistently, but in much the same way, the work which the Select Committees of the House have hitherto found themselves led into doing. The rightness of this central recommendation of the report is vouched for because it is an evolution and because all of us on the Committee found ourselves obliged to recognise it as the next development and the right development' (House of Commons Debates, 20 February 1979, c. 340). The longstanding existence of select committees, reinforced by their more extensive use in the 1960 s, thus provided a basis for procedural conservatives to support the proposals.

Foot found himself in a minority. In concluding the debate, he said 'I understand that it appears to be the will of the House that we should proceed within this Parliament to judge the matter. [HON 
This is a pre-copyedited, author-produced version of an article accepted for publication in Parliamentary Affairs following peer review. The version of record Philip Norton, Departmental Select Committees: The Reform of the Century?, Parliamentary Affairs, , gsz043 is available online at: https://doi.org/10.1093/pa/gsz043.

MEMBERS: "Hear, Hear"]' (House of Commons Debates, 20 February 1979, c. 384). In the event, the 1979 general election intervened. In the February debate, the Shadow Leader of the House, St John-Stevas, had committed his party to enabling the House to reach such a judgment (House of Commons Debates, 20 February 1979, c. 286). It was a promise reiterated in the party's election manifesto.

A commitment to providing time to vote on the recommendations was not the same as the government throwing its support behind them. The manifesto expressed 'sympathy' with the recommendations, but the commitment was to give the new House 'an early chance of coming to a decision on the proposals' (Conservative Party, 1979, p. 21). This was a compromise arising from divisions in the Shadow Cabinet, where only a minority were strongly in support (Norton, 1981, p. 231). What made the crucial difference was the speed with which the new Leader of the House, St John-Stevas, acted and the context in which he did so. He brought the Procedure Committee proposals before Cabinet just after the government had encountered an ill-tempered debate on MPs pay (Norton, 1981, p. 232). A combination of an unwillingness to face up to an assertive House, and an apparent belief that the manifesto had tied the government's hands, led the cabinet acquiescing in the proposals. Members were not supportive-only two spoke in support of St John-Stevas-but they were not prepared to prevent the House reaching a decision on the proposals. As the Spectator reported, St John-Stevas succeeded 'against much pressure from his Cabinet colleagues' (Spectator, 13 October 1979, p. 15).

The June debate was largely a rerun of that of February, but more focussed-confined as it was to motions relating to the select committees - and with the Leader of the House on this occasion supporting change. St John-Stevas managed to embrace both the radical and evolutionary views of the proposed changes. As Philip Aylett reports in his article, St John-Stevas used the evolutionary thesis to assuage the fears of the Prime Minister. In his speech, he utilised both, a point noted by his new opposite number, Merlyn Rees: 'The Leader of the House described these proposals as revolutionary, qualified later by his use of the term "evolutionary"' (House of Commons Debates, 25 June 1979, c. 51). (In the February debate, St John-Stevas had also referred to the report 'as a radical document, but not a revolutionary one'. House of Commons Debates, 20 February 1979, c. 280.) Rees appeared not too concerned by how the changes were conceptualised. He believed that the House should accept the motion 'and see what develops in the years ahead' (House of Commons Debates, 25 June 1979, c. 57). The proposals thus garnered support from both front benches.

The key vote was that approving the motion to appoint the select committees (House of Commons Debates, 25 June 1979, c. 247-250). The 12 MPs to vote against comprised 10 Labour Members and 2 Conservatives.1 Michael Foot did not vote. Amendments to appoint committees on subjects other than those covered in the report's recommendations were rejected. Not all the proposals made by the Procedure Committee were accepted, but some, such as paying committee chairs 'a modest additional salary' and providing time to debate committee reports, were to come about in the fullness of time. The 12 committees were soon supplemented by committees on Scottish and Welsh Affairs. 
This is a pre-copyedited, author-produced version of an article accepted for publication in Parliamentary Affairs following peer review. The version of record Philip Norton, Departmental Select Committees: The Reform of the Century?, Parliamentary Affairs, , gsz043 is available online at: https://doi.org/10.1093/pa/gsz043.

The House thus established a set of departmental select committees. The use of committees was not new and, as we have seen, could be supported as an extension of what had gone before. However, the scale of the change - the number and near-comprehensive coverage of government departments, established by standing order-could be characterised as a novel departure. As George and Evans recorded, it was the structure that set the committees apart (George and Evans, 1983, p. 76). When the Procedure Committee report was published in 1978, The Times lauded it as 'an historic document in British parliamentary history' (The Times, 4 August 1978). The implementation of its recommendations, including but not confined to the departmental select committees, may be seen to bear out that description.

The departmental select committees soon became a prominent feature of parliamentary life. In the 1979-1983 Parliament, they held a total of 2,140 meetings and issued 193 reports. In total, 1,312 officials - and 161 ministers - appeared before them to give evidence (see Englefield, 1984, pp. 137251). Their initial success, though, was in surviving. They benefitted from their number and the way they had come into being. There was an element of safety in numbers. They formed a comprehensive grouping. They did not lend themselves, as the Crossman committees did, to being picked off individually. They also were not seen as creatures of the executive. In effect, the way in which they had come into being, and the manner in which they were sustained in their early years, showed that they were in the ownership of the House. The fact that they were here to stay was clear when they were re-appointed at the start of the 1983 Parliament.

Since their creation, the committees have seen a period of consolidation, sporadic reforms (such as payment of committee chairs), greater links with the chamber and arguably paradigmatic change. The last of these was a result of the implementation of the recommendations of the Select Committee on Reform of the House of Commons (the Wright Committee) in 2010 (House of Commons Reform Committee, 2009, 2010). Against a backdrop of political pressure, in this case the MPs' expenses scandal of 2009, significant changes were agreed, principally in the form of the election of committee chairs by the whole House and members by the relevant parliamentary parties (see Russell, 2011). The position of committee chairs was enhanced, while the whips, who previously had become core to nominating members, lost a major patronage power.

The committees have also gone through different periods of analysis. Their early years saw several volumes devoted to assessing their role and impact. To the fore was the volume edited by Gavin Drewry, The New Select Committees, published in 1985 (with a second edition in 1989), the product of a group set up by the Study of Parliament Group. There were also works by Englefield (1984), Marsh (1986), Judge (1990), Jogerst (1993) and Hawes (1993). There were various book chapters and journal articles.

There was then something of a hiatus, at least in terms of monograph-length studies until 2011, when the Constitution Unit study by Meg Russell and Meghan Benton, Selective Influence: The Policy Impact of House of Commons Select Committees, appeared (see also Benton and Russell, 2013). It was a substantial and systematic analysis of the impact of the committees. Given that the committees exercise only a persuasive, and not (unlike public bill committees) a coercive, capacity, 
This is a pre-copyedited, author-produced version of an article accepted for publication in Parliamentary Affairs following peer review. The version of record Philip Norton, Departmental Select Committees: The Reform of the Century?, Parliamentary Affairs, , gsz043 is available online at: https://doi.org/10.1093/pa/gsz043.

assessing their impact on policy has been a challenging exercise. Using a mixed methods approach, Russell and Benton examined seven committees in the period from 1997 to 2010 . They found that around $40 \%$ of their recommendations were accepted by government, with roughly the same proportion going on to be implemented. However, as they went on to note, acceptance of recommendations was only one measure, and not necessarily the most important, of committee success. Indeed, they offered seven forms of non-quantifiable influence: 'Contributing to debate, drawing together evidence, spotlighting issues, brokering between actors in government, improving the quality of government decision-making through accountability, exposing failures, and perhaps most importantly "generating fear"'(Russell and Benton, 2011, p. 8). Even that list may not be exhaustive, as a committee may serve to mediate between different actors beyond government. The committees thus form a rich seam for analysis, but one that has not yet been fully mined.

Forty years on June 2019 saw the ruby anniversary of the departmental select committees. To mark the occasion, the Study of Parliament Group organised a two-day conference in the anniversary week (on 27 and 28 June) in the Palace of Westminster, with contributions from academics and from practitioners who had been involved in the committees, as members or clerks, over the years. There were analyses of how the committees had developed, how they have been viewed by officials and campaigners, how they compared with committees elsewhere and especially salient issues such as their powers and privileges, public engagement and the relationship of the committees to the UK's withdrawal from membership of the European Union.

The Group also undertook a linked commemoration in the form of this special issue. Some of the articles derive from papers delivered at the conference and others are commissioned specially for inclusion. They are designed to provide an overview and assessment of committees since their creation. Philip Aylett examines the introduction of the committees as part of a longer term process of development, in essence offering a Powellian perspective in contrast to the more common view of committees as a radical departure. As we have seen, there is nothing novel in the use of select committees by the House; there is an argument as to whether the introduction of a set of departmentally related select committees represents a change in scale or moving committee scrutiny to a new paradigm. Lucinda Maer and Henry Midgley also help put the introduction of the committees in context and the extent to which they go beyond the previous boundaries in terms of roles and resources. As we have noted, the National Audit Act was one of the reforms implemented in the 1979-1983 Parliament. Over time, as National Audit Office (NAO) resources have expanded, there has been a greater willingness on the part of the Comptroller and Auditor General for the NAO to assist select committees. The development has, as Midgley shows, not been the result of design, and is limited relative to its work with the Public Accounts Committee, but it constitutes a useful complement to the resources available to the committees.

Committees rely on powers conferred by the House, but to fulfil their roles effectively they are dependent on their members. How well they go about their tasks depends not only on knowing what those tasks are, but also having the time and skills-ability for forensic questioning, assessing submissions-to carry them out. MPs are increasingly pressured in terms of commitments. Prioritising workloads is an ever-growing challenge. The papers by McKay et al. (2019) Geddes and Crewe examine committees from the perspective of those who serve or have served on them. 
This is a pre-copyedited, author-produced version of an article accepted for publication in Parliamentary Affairs following peer review. The version of record Philip Norton, Departmental Select Committees: The Reform of the Century?, Parliamentary Affairs, , gsz043 is available online at: https://doi.org/10.1093/pa/gsz043.

Utilising Searing's seminal work on Members' roles, McKay et al. (2019), examine how MPs use membership in pursuit of their roles. Some MPs have effectively made careers as committee members, becoming recognised as specialists in the field covered by their committees (Bruce George on the Defence Committee for example from 1979 to 2005 and chair 1997-2005), while others have used them as means to demonstrate their suitability for ministerial office. The authors find that certain committees have been used more successfully than others as stepping stones to promotion. Marc Geddes examines committees from a different perspective, that of how the members see the role of the committees. This shapes their behaviour, with an emphasis on collegiality. In steering the work of committees, the role of chairs is recognised as core to how they operate. The perspective of those who chair or have chaired committees formed an important consideration at the 40th anniversary conference, with a panel comprising current chairs forming the opening event.

The third set of articles in the issue address the committees in action. There are different types of committees. Those covering the different nations of the UK have a different focus to others. Torrance and Evans examine committees that have had to cope with fundamental constitutional change in the nations covered. As they show, the committees have faced different challenges as a result of the asymmetrical nature of devolution as well as, in the case of the Scottish Affairs Committee, the changing political face of government in Scotland. The Northern Ireland Committee has faced a unique situation because of the collapse of the Northern Ireland executive and Brexit.

The issue of Brexit has also and obviously offered a notable challenge for the committee covering the Brexit Department, which in terms of size and behaviour (not least number of divisions) stands as something of an outlier. As Lynch and Whitaker show, it is the most divided select committee of recent times. That, though, has not prevented it advancing recommendations, with, as they record, greater success for recommendations suggesting a lower degree of change. The committee has also had a role in shaping the agenda and bringing information into the public domain.

Committees have the freedom to choose their own topics of inquiry, some going for topical inquiries, the subject of analysis by Craig Prescott, some for longer term issues and some in effect serving as advocates for specific causes, the subject of the paper by Evans and Challender. Such preferences by MPs serving on committees are essentially rational. There is a difference between the two chambers. In distributive theory, committees are the agents of individual members and in informational theory the agents of the House. The former applies to the House of Commons and the latter to the House of Lords (Norton, 2019b). MPs are more driven than peers to go for high profile, 'look at me' type activities, of the type examined in this section.

The final set of articles look at the relationship between committees and engagement with those outside Westminster, both in terms of evidence-taking (in effect, public or interested publics to Parliament) and engaging with the public in terms of awareness of what they are doing (Parliament to public). There is a growing awareness of the importance of reaching beyond the 'usual suspects' for evidence as well as of utilising social media for both inward and outward engagement. Elstub and Beswick address the evidence-gathering by committees. There is recognition of the value of drawing 
This is a pre-copyedited, author-produced version of an article accepted for publication in Parliamentary Affairs following peer review. The version of record Philip Norton, Departmental Select Committees: The Reform of the Century?, Parliamentary Affairs, , gsz043 is available online at: https://doi.org/10.1093/pa/gsz043.

on a more diverse range of witnesses, but-as they show -the traditional means of taking evidence tends to be favoured. Achieving greater diversity calls for more resources as well as a culture shift.

Walker et al., 2019 consider the role of the committees in public engagement. They draw on, but go beyond, existing theoretical works to conceptualise engagement. They identify different elements to public engagement, encompassing disseminating information about parliamentary business, both to educate and to encourage consultation and participation in committee work. For those wanting to follow what is happening in committee, one is no longer dependent on the written transcript after the event or selective coverage by broadcasters, but they can now watch committees in action. The committees themselves are active in developing engagement strategies, including through using novel means of contact, including crowdsourcing, surveys and polling. Much of this is premised on recognising the need to reach out beyond Westminster. As the authors report, the committees now have a target of $70 \%$ of engagement events and activities to be held outside of Parliament. The committees are alert to the need to reach on occasion groups that are difficult to reach. As the research of Elstrub and Beswick shows, challenges remain in developing a culture where such engagement becomes a natural feature of committee work.

The articles, individually and collectively, offer a rich assessment of 40 years of departmental select committees. The committees have changed over that time as the environment they inhabit has changed. When they were formed, papers were typewritten and there was no Internet or e-mail. Now, committee reports and evidence are available online. All committee meetings are webcast. Meetings were initially confined primarily to the Palace of Westminster. The physical environment has changed, with the opening in 2001 of a new parliamentary building, Portcullis House, providing extra capacity with a dedicated corridor of committee rooms. The physical environment will further change as a result of a programme of restoration and renewal, both Houses having to decant the Palace of Westminster, which itself may further change the culture of the institution (McCarthyCotter et al., 2018, p.59).

The significance of the departmental select committees is apparent if one thinks of what parliamentary life was like before 1979. The committees are an integral part of the life of the House of Commons. It was not certain that they would survive the first Parliament of their existence. Their centrality to the work of the Commons is apparent at the start of a Parliament if there is a delay in appointing them. From operating somewhat uncertainly at the parliamentary periphery, they have become core features of the British House of Commons.

\section{References}

Benton M., Russell M. (2013) 'Assessing the Impact of Parliamentary Oversight Committees: The Select Committees in the British House of Commons', Parliamentary Affairs , 66, 772-797.

Campion L. (1958) An Introduction to the Procedure of the House of Commons , 3rd edn, London, Macmillan \& Co. 
This is a pre-copyedited, author-produced version of an article accepted for publication in Parliamentary Affairs following peer review. The version of record Philip Norton, Departmental Select Committees: The Reform of the Century?, Parliamentary Affairs, , gsz043 is available online at: https://doi.org/10.1093/pa/gsz043.

Conservative Party (1979) The Conservative Party Election Manifesto 1979 , London, The Conservative Party.

Crick B. (1964) The Reform of Parliament, London, Weidenfeld \& Nicolson.

Crossman R. (1976) The Diaries of a Cabinet Minister , Vol. 2, London, Hamish Hamilton/Jonathan Cape.

Crossman R. (1977) The Diaries of a Cabinet Minister , Vol. 3, London, Hamish Hamilton/Jonathan Cape.

Dorey P. (2008) The Labour Party and Constitutional Reform: A History of Constitutional Conservatism , Basingstoke, Palgrave Macmillan.

Drewry G. (ed.) (1989) The New Select Committees, 2nd edn, Oxford, Oxford University Press.

Englefield D. (ed.) (1984) Commons Select Committees: Catalysts for Progress ? London, Longman.

Englefield D. (1985) The Study of Parliament Group: The First Twenty-One Years, London, Study of Parliament Group.

Expenditure Committee, House of Commons (1977) Eleventh Report, Session 1977-1978, HC 535, London, HMSO.

George B., Evans B. (1983) 'Parliamentary Reform—the Internal View', In Judge D. (ed.), The Politics of Parliamentary Reform, London, Heinemann Educational Books.

Hansard S. (1967) Parliamentary Reform: A Survey of Recent Proposals for the Commons , 2nd edn, London, Cassell.

Hawes D. (ed.) (1993) Power on the Back Benches? The Growth of Select Committee Influence, Bristol, SAUS Publications. 
This is a pre-copyedited, author-produced version of an article accepted for publication in Parliamentary Affairs following peer review. The version of record Philip Norton, Departmental Select Committees: The Reform of the Century?, Parliamentary Affairs, , gsz043 is available online at: https://doi.org/10.1093/pa/gsz043.

Hill A., Whichelow A. (1964) What's Wrong with Parliament ? Harmondsworth, Penguin Books.

House of Commons Reform Committee, House of Commons (2009) Rebuilding the House, First Report, Session 2008-2009, HC 1117, London, HMSO.

House of Commons Reform Committee, House of Commons (2010) Rebuilding the House: Implementation , First Report, Session 2009-2010, HC 372, London, HMSO.

Johnson N. (1979) 'Select Committees and Administration'. In Walkland S. A. (ed.), The House of Commons in the Twentieth Century, Oxford, Clarendon Press.

Jogerst M. (1993) Reform in the House of Commons, Lexington, Kentucky, KY, University Press of Kentucky.

Judge D. (1990) Parliament and Industry, Aldershot, Dartmouth.

King A. (1976) 'Modes of Executive-Legislative Relations: Great Britain, France, and West Germany', Legislative Studies Quarterly , 1, 11-34.

McCarthy-Cotter L.-M., Flinders M., Healey T. (2018) 'Design and Space in Parliament'. In LestonBandeira C., Thompson L. (eds), Exploring Parliament , Oxford, Oxford University Press.

Mackenzie K. (1968) The English Parliament, revised edn, Harmondsworth, Penguin Books.

Marsh I. (1986) Policy-Making in a Three-Party System, London, Methuen.

McKay S., Goodwin M., Bates S. H. (2019) 'A Means to an End and an End in Itself: Select Committee Membership, Parliamentary Roles and Parliamentary Careers, 1979-Present'. Parliamentary Affairs, doi:10.1093/pa/gsz038.

Ministry of Reconstruction (1918) Report of the Machinery of Government Committee, Chair: Viscount Haldane of Cloan, London, HMSO.

Norton P. (1978) Conservative Dissidents, London, Martin Robertson. 
This is a pre-copyedited, author-produced version of an article accepted for publication in Parliamentary Affairs following peer review. The version of record Philip Norton, Departmental Select Committees: The Reform of the Century?, Parliamentary Affairs, , gsz043 is available online at: https://doi.org/10.1093/pa/gsz043.

Norton P. (1980) Dissension in the House of Commons 1974-1979, Oxford, Clarendon Press.

Norton P. (1981) The Commons in Perspective , Oxford, Martin Robertson.

Norton P. (1983) 'The Norton View'. In Judge D. (ed.), The Politics of Parliamentary Reform , London, Heinemann Educational Books.

Norton P. (1986) 'Independence, Scrutiny and Rationalisation: A Decade of Changes in the House of Commons', Teaching Politics , 15, 69-97.

Norton P. (2019a) 'Is The House of Commons Too Powerful? The 2019 Bingham Lecture in Constitutional Studies, University of Oxford', Parliamentary Affairs, doi: 10.1093/pa/gsz022.

Norton P. (2019b) 'Post-Legislative Scrutiny in the UK Parliament: Adding Value', The Journal of Legislative Studies , 25, doi: 10.1080/13572334.2019.1633778.

Procedure Committee, House of Commons (1978) First Report, Session 1977/78, HC 588-I, London, HMSO.

Russell M. (2011) "Never Allow a Crisis to Go to Waste": The Wright Committee Reforms to Strengthen the House of Commons', Parliamentary Affairs , 64, 612-633.

Russell M., Benton M. (2011) Selective Influence: The Policy Impact of House of Commons Select Committees, London, The Constitution Unit.

Sedgwick R. (1970) The House of Commons 1715-1754 , vol. I, London, HMSO for the History of Parliament Trust.

Walker A., Jurczak N., Bochel C., Leston-Bandeira C. (2019) ‘How Public Engagement Became a Core Part of the House of Commons Select Committees', Parliamentary Affairs, doi:10.1093/pa/gsz031. 